\title{
Hijab dalam Pandangan Muslimah
}

\section{(Studi Living Quran Komunitas Muslimah Peduli Hijab Purwokerto)}

\author{
Ken Ayu Kartikaningrum \\ IAIN Purwokerto \\ Jl. A. Yani No. 40A \\ Purwanegara, Kec. Purwokerto Utara \\ E-Mail: ayuken97@gmail.com
}

\begin{abstract}
Abstrak
Artikel ini membahas tentang hijab dalam pandangan komunitas Muslimah Peduli Hijab Purwokerto. Penelitian ini merupakan jenis penelitian lapangan atau field research. Dalam menganalisis data, instrumen yang peneliti gunakan adalah wawancara mendalam, observasi, dan data-data yang peneliti dapatkan dari jurnal, buku, maupun surat kabar. Peneliti dalam hal ini menggunakan Teori Konstruksi sosial dari teori Peter L Berger Teori ini lebih fokus terhadap makna dan penafsiran bersama yang dikonstruksi dalam jaringan masyarakat. Dari penelitian yang dilakukan, peneliti fokus dua hal utama yaitu: (1) Pandangan komunitas Muslimah Peduli Hijab Purwokerto terhadap hijab. (2) Genealogi pemahaman hijab komunitas Muslimah Peduli Hijab Purwokerto.
\end{abstract}

Kata kunci: Hijab, Muslimah, Aurat, dan Genealogi

\begin{abstract}
Abstrack
This article discusses the hijab in the view of the Muslim community Caring for the Hijab Purwokerto. This research is a type of field research. In analyzing data, the instruments that researchers use are in-depth interviews, observations, and data that researchers get from journals, books, and newspapers. Researchers, in this case, use the Social Construction Theory from Peter L Berger's theory. This theory is more focused on the meaning and joint interpretation constructed in community networks. From the research conducted, the researchers focused on two main things, namely: (1) The view of the Muslim community caring for Hijab Purwokerto on the hijab. (2) Genealogy of Muslim Hijab Care for Hijab Purwokerto community understanding hijab.
\end{abstract}

Keywords: Hijab, Muslim Women, Aurat, and Genealogy

\section{A. Pendahuluan}

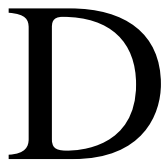

ewasa ini, ditemukan banyak sekali permasalahan tentang aurat perempuan. Bagi sebagian orang, pamer aurat dianggap seni. Perzinaan di anggap zamannya dan pembunuhan janin (aborsi) dianggap hak asasi. 
Maka lahirlah generasi instan, yaitu generasi yang tidak memiliki kepedulian terhadap moral (Al-Ghifari, 2003, p. 13). Kehidupan yang serba modern dan banyak terpengaruh globalisasi menyebabkan sebagian masyarakat Islam, khususnya perempuan muslimah kembali ke zaman Jahiliyah. Hal ini dapat dilihat dari bagaimana cara mereka berbusana, berhias dan bersolek dalam kehidupan sehari-hari, terutama dalam hal berhijab.

Banyak wanita berhijab dikarenakan mengikuti mode atau trend saat ini, sehingga beberapa muslimah melupakan tujuan dasar berhijab yakni menutup aurat. Misalnya, mereka mengenakan hijab tipis dan minimalis, sehingga tidak menutup bagian anggota tubuh yang seharusnya ditutupi, seperti leher, dada dan lekukan tubuh. Sebaliknya, jika ada muslimah yang menutup aurat dengan berhijab melebihi batas umum, misalnya memakai gamis longgar, kerudung besar hingga lutut atau yang terlihat hanya kedua telapak tangan dan mata, maka akan diberi 'label' menyimpang, radikal bahkan dipandang bagian dari kelompok teroris. Lebih jauh lagi, Muslimah yang berhijab besar dipandang sebelah mata karena membatasi diri dengan lingkungan dan masyarakat sehingga dianggap anti social.

Islam yakni agama yang sesuai untuk masa lalu, masa kini dan masa depan. Kehendak agama Islam ialah ketentraman dalam pergaulan, kebebasan yang dibatasi oleh aturan syara', penjagaan yang mulia setiap pribadi baik laki-laki maupun perempuan (Amrullah, 2003, v. 7, p. 4930). Islam hendak membawa manusia ke puncak kemanusiaan bukan malah turun ke bawah hingga menjadi binatang, salah satunya adalah dengan menetapkan peraturan tentang hijab.

Manusia laki-laki dan perempuan diberi syahwat kelamin(sex) agar supaya mereka jangan punah dan musnah dari muka bumi ini. Apabila sekali syahwat yang tidak terkendali itu telah menguasai kelamin, sukarlah bagi seseorang melepaskan diri daripada kungkungannya, oleh karena itu usaha yang pertama ialah menjaga penglihatan mata. Menahan penglihatan mata itu adalah menjamin kebersihan dan ketentraman jiwa. Peringatan kepada perempuan, selain menjaga penglihatan mata dan memelihara kemaluan, ditambah lagi janganlah dipertontonkan perhiasan mereka kecuali yang nyata saja. Cincin di jari, muka dan tangan, itulah perhiasan yang nyata. Artinya yang sederhana dan tidak mencolok. Kemudian diterangkan pula bahwa hendaklah selendang (kudung) yang telah memang tersedia ada di kepala itu ditutupkan kepada dada (Amrullah, 2003, v. 7, p. 4924).

Al-Qur'an dan hadist merupakan sumber dalam menetapkan suatu aturan dan hukum. Secara umum konsep hijab pun tidak terlepas dari keduanya. Pemahaman sesorang menyangkut nash (termasuk al-Quran dan Hadits) tidak terlepas dari pengaruh perkembangann ilmu pengetahuan dan budaya masyarakatnya, di samping kecerdasan 
dan kecenderungan pribadinya (Shihab, 2004, p. 68). Dari pandangan inilah, sedikit banyak mempengaruhi pemikiran dalam aturan menutup aurat, seperti contoh yang dilakukan oleh komunitas Muslimah Peduli Hijab Purwokerto. Meski terkesan berhijab lebar dan besar namun mereka memiliki jiwa sosial yang tinggi dan bukan merupakan kelompok teroris.

\section{B. Profil Komunitas Muslimah Peduli Hijab Purwokerto}

Komunitas ini berawal dari group WhatsApp (WA) untuk mendata peserta Gerakan Menutup Aurat (GEMAR) pada Februari 2017. Gerakan Menutup Aurat ialah kegiatan membagi-bagikan busana muslim dan muslimah berupa pakaian, sarung, jilbab, kerudung hingga peralatan sholat serentak di beberapa kota di Indonesia, salah satunya ialah kota Purwokerto.1 Kegiatan ini dilaksanakan oleh kumpulan dari beberapa komunitas pemuda Banyumas Setelah kegiatan berakhir, beberapa peserta GEMAR menginginkan untuk membuat sebuah komunitas yang berfokus pada syariat Muslimah. Setelah melakukan diskusi yang panjang melalui WhatsApp, maka terbentuklah sebuah Komunitas yang dinamakan "Muslimah Peduli Hijab Purwokerto", dengan misi memasyarakatkan hijab syar'i khususnya di daerah Purwokerto.2

Anggota komunitas mulai dari kalangan pelajar Sekolah Menengah Pertama (SMP), Sekolah Menengah Atas (SMA/MA), Perguruan Tinggi (PTN/PTS), pebisnis Muslimah, hingga muslimah yang sudah berkeluarga. Dengan slogan "Satukan Hati Menuju Syar'i". Komunitas ini terdiri dari 132 anggota dengan background yang berbeda. Kesekretariatan MPHP berada di Komplek Buaran Indah, Jl. Gunung Galunggung RT 05 RW 06, Pabuaran, Purwokerto (Utara Makam Grendeng).

MPHP memiliki visi dan misi yang dibangun bersama demi tercapainya tujuan pembentukan komunitas ini

VISI MPHP

"Satukan hati menuju syar'i".

MISI MPHP

"Menerima untuk memberi".

Komunitas Muslimah Peduli Hijab Purwokerto memiliki beberapa divisi, yakni:

1. Divisi Kerohanian

a) Dalam Negri

1 Wawancara Dengan Ayon, Mahasiswi Universitas Jenderal Soedriman Sekaligus Ketua Komunitas Muslimah Peduli Hijab Purwokerto Periode 2018/2019 pada 19 Maret 2019

${ }^{2}$ Wawancara Dengan Liring, Penasehat Komunitas Muslimah Peduli Hijab Purwokerto pada 8 Mei 2019 
Melakukan kajian rutin dan diskusi komunitas agar anggota komunitas memiliki pondasi yang kuat sehingga mampu untuk berdakwah di masyarakat luas. Tema diskusi yakni berupa

b) Luar Negri

Kajian dan diskusi dengan masyarakat luas baik melalui radio maupun mengadakan kajian pada beberapa masjid di wilayah Purwokerto.

\section{Divisi sosial}

Mengadakan bakti sosial, bazar murah dimana hasil yang diperoleh akan disumbangkan kepada orang yang membutuhkan seperti anak yatim, janda dhufa dan fakir miskin. Selain itu, komunitas ini juga melaksanakan open donasi dan galang dana ketika terjadi musibah yang terjadi di Indonesia, seperti tsunami Palu dan Donggala, gempa Lombok, longsor Banten dan beberapa daerah lain.

\section{Usaha Dana}

Melakukan usaha mencari dana, sponsor dan berkoordinasi dengan masyarakat luar.

2. Umum

Aktif dalam menginformasikan dan menyebarkan kegiatan di media sosial, seperti di blog, WhatsApp, Instagram, Facebook dan Twitter.

Komunitas Muslimah Peduli Hijab Purwokerto memiliki ciri tersendiri dalam berpakaian. Anggota komunitas ini memiliki beberapa tipe dalam berpakaian:

a. Kelompok pertama

Muslimah yang memakai pakaian longgar berwarna gelap, mengenakan handstock, menutup kepalanya dengan kain yang lebar hingga hampir menutup seluruh badannya dan yang terlihat hanyalah kedua mata dan ujung jarinya. Dapat dilihat dari gambar di bawah ini:
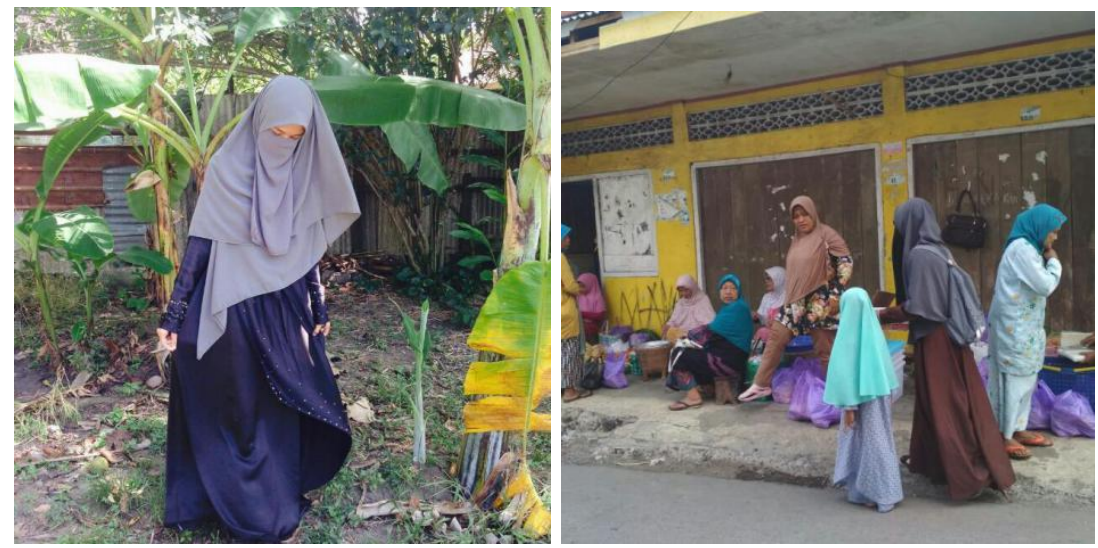

b. Kelompok kedua 
Muslimah yang memakai pakaian longgar berwarna cerah, mengenakan handstock, menutup kepalanya dengan kain yang lebar hingga hampir menutup seluruh badannya dan yang terlihat hanyalah kedua mata dan ujung jarinya. Berikut karakteristik Muslimah ini:

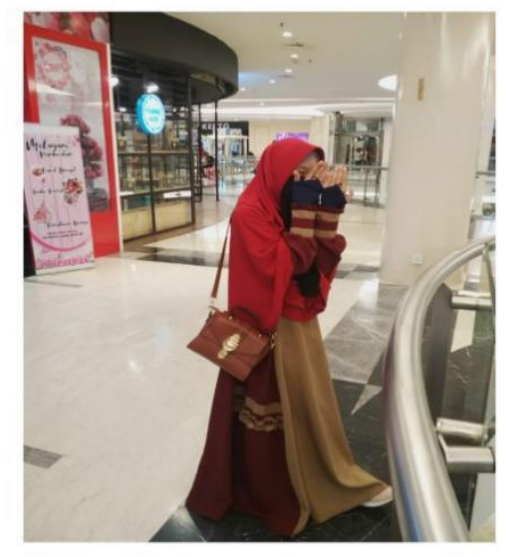

c. Kelompok ketiga

Muslimah yang memakai pakaian tidak terlalu longgar (standar namun tidak menampakan bentuk tubuh) tidak mempermasalahkan warna namun mengenakan penutup kepala yang lebar hingga menjulur ke dada.
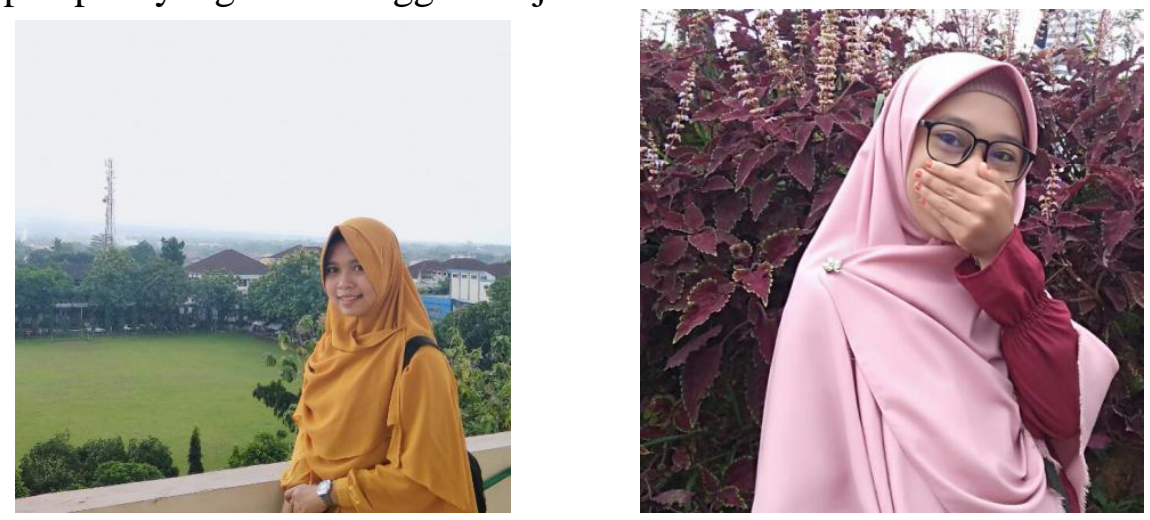

Uniknya, dalam setiap kegiatan besar, anggota komunitas tersebut diwajibkan mengenakan pakaian longgar yang berwarna ungu dan diwajibkan berwudu serta membawa al-Qur'an. Sebelum mengawali kegiatan mereka bertadaruss al-Qur'an namun yang dibaca hanya surat pilihan, seperti surat Yasin, ar-Rahman, al-Waqi'ah, dan al-Mulk.

Komunitas fokus terhadap hijab dan sosial yang berorientasi pada perempuan. Salah satu kegiatan rutin tahunan yaitu membagi-bagikan hijab kepada masyarakat di bulan Februari yang terkenal dengan peringatan valentine, dengan adanya kegiatan ini mereka berharap pola pikir masyarakat Islam yang awalnya memperingati valentine 
dengan 'hadiah coklat, bunga' bergeser menjadi semangat untuk menutup aurat. Meskipun terbilang 'muda' namun komunitas ini sudah berhasil merambah beberapa wilayah lain seperti kegiatan baksos yang targetnya berupa perempuan lansia di Brebes dan Tegal, santunan anak yatim di Cilongok, pemberian bantuan kepada Taman Pendidikan al-Quran, diantaranya yakni pengajar agama yang lumpuh di Ajibarang (alQuran, Nahwu, dan beberapa peralatan sholat lainnya).

\section{Pandangan Hijab Komunitas Muslimah Peduli Hijab Purwokerto}

Komunitas Muslimah Peduli Hijab Purwokerto memaknai hijab dengan beragam pemaknaan. Secara umum pemaknaan hijab tidak terlepas dari al-Qur'an, Hadits dan buku keagamaan lainnya. Seperti yang diutarakan oleh Liring Tyas :

"Hijab berarti tabir, penghalang atau segala sesuatu yang mampu menutupi diri baik secara fisik (anggota tubuh) maupun batin (hawa nafsu, akhlak dan berhubungan dengan manusia), salah satu contoh hijab batin ya membatasi pergaulan dengan lawan jenis. Jadi kalo jilbab, khimar dan selendang merupakan bagian dari hijab. Sedangkan kalau jilbab cenderung berorientasi pada makna pakaian."3

Pendapat lain yang hampir serupa dikemukakan oleh Devi Atikah selaku ketua Komunitas Muslimah Peduli Hijab Purwokerto Periode 2017:

"Seperti yang kita tau, banyak macam bentuk hijab dari ujung kepala sampai ujung jari kaki. Entah itu khimar, bergo, gamis dan perlengkapannya seperti kaos kaki, handsock pun tak luput dari perhatian. Hijab itu memuliakan wanita, bukan hanya sebagai penutup. Kehormatan wanita ada pada dirinya sendiri dalam cara berperilaku, berpakaian, bersosialisasi dan banyak lagi hal-hal lain yang kita sendiri membutuhkan hijab. Hijab sendiri bukan sekedar pakaian namun juga gaya hidup. Kebiasaan membatasi diri dari pergaulan bebas itu juga termasuk hijabnya diri".

Adapun aktifis Ikatan Mahasiswa Muhammadiyah atau biasa disebut IMM memberikan pemahamannya mengenai hijab sebagai berikut:

"Hijab ialah sesuatu yang menutup aurat. Hijab terdiri dari jilbab (baju gamis longgar dan Panjang), khimar (kain penutup kepala yang menjulur hingga bagian dada dan tidak menampakan lekuk tubuh). Hijab bisa jadi gorden, satir, tembok ataupun segala sesuatu yang menutup. Jilbab ialah baju gamis yang longgar dan Panjang. Kerudung ialah ciput (dalaman kerudung), khimar ialah penutup kepala yang dipakai. Umumnya Muslimah Indonesia menyebut penutup kepala dengan jilbab. Kalo gitu, makna jilbab berarti 'khimar' dalam Bahasa saya. Jilbab nggak mesti gede, karena setiap orang beda-beda fisiknya. Ada yang punya badan kecil,

${ }^{3}$ Wawancara dengan Liringtyas, Penasehat Komunitas Muslimah Peduli Hijab Purwokerto pada 8 Mei 2019 
besar dan sedang. Yang terpenting itu dia menutup dadanya dan menutupi lekukan tubuhnya. Jadi yang terpenting menutup yang seharusnya ditutup". 4

Dari informasi di atas dapat disimpulkan bahwa mayoritas anggota Komunitas Muslimah Peduli Hijab Purwokerto memberikan pemaknaan tentang hijab menjadi 2 makna yakni:

1. Hijab adalah tabir atau penghalang yang menghalangi atau membatasi antara 2 hal atau yang menghalangi terlihatnya sesuatu yang berada di belekangnya. Misalnya pengahalang antara laki-laki dan perempuan dalam bergaul, pembatas rumah yang berfungsi agar tamu tidak langsung ke bagian rumah yang lebih dalam.

2. Hijab adalah penutup yang menutupi bagian tubuh seseorang (dalam bentuk apapun) yang tidak diperkenanan untuk dipertontonkan kepada sembarang orang. Misalnya orang Indonesia memaknai penutup muka dan yang terlihat hanya mata dengan 'cadar', kain penutup kepala, leher dan dada dengan 'khimar' dan kain penutup tubuh dengan 'gamis'.

Adapun konsep hijab dalam hal menutup ialah kain yang digunakan untuk menutup aurat atau sesuatu yang tidak seharusnya ditampakkan, seperti menutup bagian kepala, leher hingga dada dan tidak menampakan bentuk lekukan tubuhnya dan perhiasannya. Namun mengenai masalah warna hijab terdapat beberapa perbedaan:

a. Kelompok pertama berpandangan bahwa warna yang digunakan dalam berhijab haruslah warna-warna yang gelap seperti hitam, navy, coklat dan abu-abu. Hal ini nampaknya dapat didasarkan pada beberapa dalil fiqih. Dalam suatu buku fiqih disebutkan mengenai kriteria hijab. Adapun kriteria hijab yang tanpanya hijab itu tidak sah, yaitu (Uwaidah, 2017, p. 548):

1) Harus menutupi seluruh badan kecuali wajah dan dua telapak tangan

2) Bukan sebagai hiasan bagi dirinya, sehingga tidak boleh memakai kain yang mencolok, atau kain yang penuh hiasan.

3) Harus lapang dan tidak sempit sehingga tidak menggambarkan postur tubuhnya

4) Tidak boleh memperlihatkan sedikit pun bagi kaki perempuan

5) Tidak boleh sobek, sehingga tidak menampakkan bagian tubuh atau perhiasan perempuan. Dan juga tidak boleh menyerupai laki-laki.

b. Kelompok kedua berpandangan bahwa warna yang digunakan dalam berhijab tidak harus warna gelap.

c. Kelompok ketiga berpandangan bahwa warna yang digunakan dalam berhijab bebas, tidak ada paksaan. memakai warna-warna gelap bukan merupakan

4 Wawancara dengan Eka Agustina Damayanti, mahasiswi aktifis IMM yang dinobatkan menjadi Mbekayu (duta) Prodi Pendidikan Agama Islam, Fakultas Tarbiyah Dan Ilmu Keguruan 2016 pada 23 Maret 2019 
kewajiban. Muslimah boleh mengenakan warna apa saja selama memenuhi standar pakaian syar'i asal menutupi yang seharusnya ditutupi sehingga kelompok ini mengenakan hijab ungu, merah muda, merah, kuning, biru langit dan warna cerah lainnya.

Ada perbedaan diantara 3 kelompok di atas dalam hal menutup wajah. Adapun kelompok pertama dan kedua berpendapat bahwa menutup wajah ialah sunah, sedangkan kelompok ketiga berpandangan bahwa menutup wajah ialah mubah. Seperti yang dapat dilihat di bawah ini:

"Muslimah disunahkan pakai penutup muka, berkaca dari wanita muslimah daerah Arab yang pake niqab, demi menghindari fitnah dan hal lainnya yang dianggap tidak baik".

"Niqab hukumnya mubah, terlebih di Indonesia muslimah umumnya tidak mengenakan penutup wajah jadi alangkah lebih baiknya kita dapat memposisikan diri dengan baik". 6

Secara umum mengenai hakikat hijab antara kelompok yang satu dengan lainnya memiliki pandangan yang sama. Hijab bukan membalut tubuh tapi menutupi. Hal ini bermakna berhijab tidak boleh terawang, tipis, transparan, press atau kurang bahan lainnya yg ketika dipakai maka akan tergambar bagaimana wujud asli badan kita. Allah menjelaskan beberapa tujuan pemakaian hijab dalam beberapa seperti dalam surat AlA'raf ayat 26. Allah SWT berfirman:

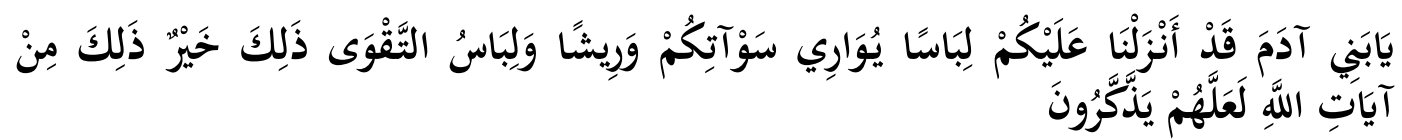

"Wahai anak Adam, sesungguhnya Kami telah menurunkan kepadamu pakaian untuk menutupi auratmu dan pakaian indah untuk perhiasan dan pakaian taqwa itulah yang paling baik".

\section{Genealogi Pemahaman Hijab Komunitas Muslimah Peduli Hijab PURWOKERTO}

Genealogi berasal dari kata dasar gene, yaitu plasma pembawa sifat-sifat keturunan. Geneologi berarti ilmu yang mempelajari masalah keturunan. Genealogi atau nasab علم الأنساب adalah kajian tentang keluarga dan penelusuran jalur keturunan serta sejarahnya. Ahli genealogi menggunakan berita dari mulut ke mulut untuk mendapatkan informasi mengenai suatu keluarga. Perkembangan genealogi ini merambah pada ranah pemikiran dan keilmuwan lainnya. Sederhananya, genealogi merupakan muara atau asal muasal suatu pemahaman. Seperti yang kita ketahui, seseorang mudah menjustifikasi atau memberi label pada kelompok lainnya hanya

\footnotetext{
${ }^{5}$ Wawancara dengan Rose, Mahasiswi Magelang pada tanggal 17 Mei 2019 pukul 16.09 WIB

${ }^{6}$ Wawancara dengan Ulil, Anggota MPHP yang aktif dalam organisasi IPPNU Ranting Cilongok
} 
karena perbedaan pemahaman. Dengan mengetahui genealogi pemahaman mereka tentang hijab maka diharapkan masyarakat tidak mudah memberi label jelek atau bahkan mengkafirkan kelompok lain.

Dalam beberapa kesempatan kita dapat menemukan sejumlah komunitas yang taqlid pada pemimpin (orang yang dianggap mumpuni) tanpa mengetahui alasan dan dalil yang jelas, seperti dalam komunitas bonokeling, dimana komunitas bonokeling mendasarkan segala aktifitasnya sesuai dengan ajaran turki (tutur kaki). Salah satunya mengenai Kitab suci yang mereka jadikan pedoman hidup, bukanlah kitab suci AlQur'ān namun Kitab Turki atau tuturing kaki (petuah-petuah nenek moyang) (Novelia, 2019).

Pemahaman hijab dalam komunitas ini tidak didoktrin oleh pemimpin ataupun penasehat komunitas, tetapi dibangun oleh kesadaran dan latar belakang individu. Artinya didasarkan atas kepercayaan. Secara umum, peneliti menyimpulkan bahwa pemahaman hijab mereka berdasarkan dari Al-Qur'an, namun lebih jauh peneliti membagi dua genealogi pemahaman secara spesifik, yakni:

1. Genealogi berdasarkan tokoh yang dijadikan panutan

Peneliti melakukan wawancara mengenai tokoh ulama yang mempengaruhi pemahaman hijab mereka. Umumnya, alasan ulama tersebut menjadi idola ialah karena ketika berdakwah memberikan kesan tersendiri, sehingga mengambil hati pendengarnya. Lambat laun tertarik dan mengikuti beberapa kajian baik dari youtube maupun secara langsung. Beberapa anggota komunitas ini menyebutkan tokoh terkenal di televisi. Jika dilihat dari ulama yang dijadikan pedoman dalam pemahaman hijab mereka cenderung pada pendapat beberapa ulama yang menimba ilmu di luar Negeri, seperti:

a. Libya yakni Adi Hidayat

b. Madinah yakni Syafiq Basalamah dan Khalid Basalamah

c. Yaman yakni Buya Yahya

d. Riyad yakni Umar Mitta

e. Mekkah, dari kalangan ustadzah yakni Oki Setiana Dewi

2. Genealogi berdasarkan keluarga

Keluarga merupakan lingkungan pertama bagi individu dimana ia berinteraksi dan kepribadian dasar individu. Pendidikan keluarga akan membentuk kepribadian anak. Orangtua adalah peletak dasar, pembangun potensi, serta "perancang awal" terbentuknya karakter individu. Begitu juga lingkungan, sekolah, keluarga, dan 
masyarakat memiliki peran yang sangat penting dan dominan dalam mengembangkan potensi diri seseorang (Novianti, 2008, p. 251).

Rasulullah bersabda Saw:

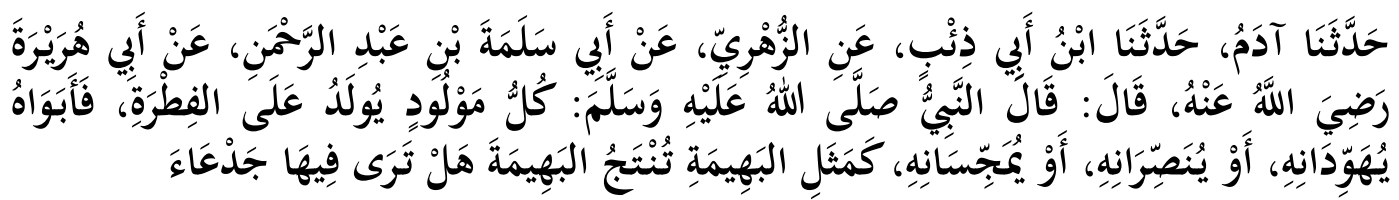

Dari Abu Hurairah r.a. telah bersabda Nabi Muhammad Saw: Setiap anak dilahirkan dalam keadaan suci, maka kedua orang tuanyalah yang menjadikannya yahudi, nasrani, atau majusi. ( HR. Bukhari )

Dari hadits diatas, jelaslah bahwa anak dilahirkan dalam keadaan fitrah (suci) dan memiliki pembawaan ketauhidan yang harus dibimbing sejak dalam fase anak-anak, remaja hingga fase dewasa. Agar setiap perkembangannya dilalui dengan baik dan benar berdasarkan pada pembinaan menurut syari'at islam. Karena tujuan pembinaan akhlak anak dalam keluarga yaitu menjadikan generasi-generasi penerus bangsa yang beriman dan beramal sholeh serta berakhlakul karimah serta mampu menerima perbedaan pendapat.

\section{E. Pemahaman HiJab Dalam Teori Konstruksi Sosial}

Teori konstruksi sosial merupakan salah satu upaya Peter L. Berger untuk menjawab barbagai persoalan dalam ranah sosiologi pengetahuan. Teori konstruksi sosial dalam gagasan Berger mengandaikan bahwa agama sebagai bagian dari kebudayaan, merupakan konstruksi manusia. Artinya ada proses dialektika ketika melihat hubungan masyarakat dengan agama, bahwa agama merupakan entitas yang objektif karena berada di luar diri manusia. Dengan demikian, agama mengalami proses objektivasi, seperti ketika agama berada dalam teks atau menjadi tata nilai, norma, aturan dan sebagainya. Teks kemudian mengalami proses internalisasi ke dalam diri individu, sebab agama telah diinterpretasikan oleh masyarakat untuk menjadi pedomannya. Agama juga mengalami proses internalisasi karena ia menjadi acuan norma dan tata nilai yang berfungsi menuntun dan mengontrol masyarakat (Berger \& Luckman, 1990, pp. 33-36). Individu menjadi penentu dalam dunia social yang dikonstruksi berdasarkan kehendaknya. Individu bukan korban social namun sebagai mesin produksi sekaligus reproduksi yang kreatif dalam mengkonstruksi dunia sosialnya. Dapat diambil kesimpulan bahwa pendek kata, Berger dan Luckman mengatakan terjadi dialektika antara individu menciptakan masyarakat dan masyarakat menciptakan individu. Proses dialektika terjadi melalui 3 hal :

\section{Eksternalisasi}


Pengungkapan gagasan seseorang (subyektifitas) melalui serangkaian aktifitas yang dilakukan secara terus menerus. Keberadaan manusia tidak mungkin berlangsung dalam suatu lingkungan yang tertutup dan tanpa gerak. Ini menandakan bahwa pandangan komunitas Muslimah peduli hijab purwokerto terhadap hijab menegaskan bahwa mereka memiliki basis historis dan dasar normatifnya sendiri. Pemahaman mereka berasal dari tokoh yang dipanutnya dan keluarga sebagai pondasi awal pembentukan kepribadian.

\section{Objektivasi}

Hasil aktivitas manusia disebarluaskan ke orang lain sehingga bisa terjadi pemaknaan baru atau pemaknaan tambahan. Lewat objektivasi, masyarakat menjadi suatu realitas sui generis. Dalam hal genealogi pemahaman, maka seorang guru menginformasikan kepada muridnya tentang pemahaman hijab yang dipahaminya atau mereka membaca dalam buku yang dijadikan rujukan. Hasil pemikiran MPHP tentang hijab diinformasikan ke orang lain, baik dalam kajian, syiar lewat media social maupun deklarasi hijab yang didalamnya terdapat syiar ke masyarakat luas.

\section{Internalisasi}

Penyerapan kembali aktivitas atau pemikiran luar ke dalam kesadaran individu atau diterapkan dalam kehidupan sehingga muncul identitas baru. Komunitas Muslimah Peduli Hijab Purwokerto melihat dan menganalisis dunia luar serta menerapkannya dalam kehidupan pribadi, berupa penerimaan atau penolakan sehingga menciptakan suatu identitas tersendiri. Dalam tahap ini, anggota komunitas ini menerima perbedaan pemahaman hijab masyarakat luar yang beragam dan mereka tetap menerapkan pemahaman sehingga menciptakan suatu identitas tersendiri yakni Muslimah yang berhijab syar'i namun tetap modis dan kekinian.

\section{F. Simpulan}

Dari hasil pembahasan, maka dapat disimpulkan temuan penting berikut ini:

Komunitas Muslimah Peduli Hijab Purwokerto merupakan komunitas yang memfokuskan dirinya pada Muslimah dan hijab juga merambah di bidang sosial. Komunitas Muslimah Peduli hijab Purwokerto terdiri dari 132 anggota dengan latar belakangnya masing-masing. Dengan perbedaan latar belakang tersebut maka terbentuklah perbedaan pemahaman dalam hal hijab. Secara umum, Komunitas ini mengartikan hijab dengan dua makna. Pertama, Hijab sebagai penutup aurat yang terdiri dari jilbab (pakiaan longgar), khimar (penutup kepala, leher dan dada), cadar (kain yang menutup wajah sehingga yang terlihat hanya kedua matanya) dan selendang. Hijab adalah penutup yang menutupi bagian tubuh seseorang (dalam bentuk apapun) 
yang tidak diperkenankan untuk dipertontonkan kepada sembarang orang. Misalnya orang Indonesia memaknai penutup muka dan yang terlihat hanya mata dengan 'cadar', kain penutup kepala, leher dan dada dengan 'khimar' dan kain penutup tubuh dengan 'gamis'. Menurut mereka, berhijab merupakan kewajiban seorang Muslimah dan juga merupakan bentuk ketaatan. Muslimah berhijab untuk menjaga kehormatanya. Menurut mereka, Muslimah hendaknya menutup auratnya dengan hijab seperti khimar, hilbaba, niqab dan lain sebagainya. Muslimah yang mengenakan cadar lebih aman dari pada yang tidak mengenakan cadar. Beliau menekankan bahwa Muslimah yang bercadar lebih aman daripada Muslimah yang tidak menutup wajahnya, tapi satu hal yang harus ditekankan bahwa kita tidak boleh merendahkan orang lain yang, baik yang tidak mengenakan cadar atau mengenakan cadar bahkan Muslimah yang tak berhijab. Kedua, Hijab sebagai penghalang yang menghalangi percampurbauran antara muslim dan Muslimah yang bukan mahram dalam pergaulan. Hijab juga diartikan sebagai pembatas hawa nafsu yang terdapat dalam diri kita.

Genealogi atau asal-usul pemahaman mereka tentang hijab dibagi menjadi 2 Pertama, bermuara pada ulama yang menimba ilmu di luar Negri seperti Libya (Adi Hidayat), Madinah (Syafiq Basalamah, Khalid Basalamah), Yaman (Buya Yahya), Mekkah (Oki Setiana Dewi), Riyadh (Umar Mitta). Kedua, bermuara pada keluarga. Sejak kecil keluarga telah mendidik dan menanamkan konsep hijab meski tidak dijelaskan dengan dalil secara detail. Secara umum, peneliti menyimpulkan bahwa mereka searah dengan konsep hijab buya yahya. Buya yahya berpendapat bahwasannya Muslimah wajib menutup seluruh auratnya kecuali wajah dan telapak tangan, namun hal ini tentunya disesuaikan dengan kondisi dan adat daerahnya. Ketika terjadi suatu permasalahan maka konsep hijab dapat berubah sesuai masalah yang ada.

\section{G. Daftar Pustaka}

Al-Ghifari, A. (2003). Remaja Korban Mode. Bandung: Mujahid Press.

Amrullah, A. A. (2003). Tafsir Al-Azhar. Singapura: Pustaka Nasional Pte Ltd Singapura.

Berger, P. L., \& Luckman, T. (1990). Tafsir Social Atas Kenyataan. Jakarta: LP3ES.

Novelia, I. (2019). Al-Quran Dalam Perspektif Masyarakat Islam Kejawen dan Implikasinya Terhadap Kehidupan Praksis (Skripsi). Ushuluddin, Adab Dan Humaniora IAIN Purwokerto, Purwokerto.

Novianti, I. (2008). Peran Ormas Islam Dalam Membina Keberagamaan Remaja. Komunika; Jurnal Dakwah Dan Komunikasi, II(2), 251. 
Shihab, M. Q. (2004). Jilbab. Jakarta: Lentera Hati.

Uwaidah, K. M. (2017). Fiqih Wanita (A. Z. Dachlan, Trans.). Depok: Fathan Media Prima. 